\title{
Productivity of kelp (Laminaria spp.) near the southern limit in the Northwestern Atlantic Ocean
}

\author{
Margaret M. Brady-Campbell ${ }^{1 *}$, David B. Campbell ${ }^{2 *}$ and Marilyn M. Harlin ${ }^{1}$ \\ ${ }^{1}$ Botany Department, University of Rhode Island, Kingston, Rhode Island 02881, USA \\ 2 Zoology Department, University of Rhode Island, Kingston, Rhode Island 02881, USA
}

\begin{abstract}
Annual primary production of kelp Laminaria saccharina was calculated from standing crop, density, tissue carbon content and growth rate measurements at 3 sites in Rhode Island, USA -2 within Narragansett Bay and 1 in Rhode Island Sound. Results indicate similar seasonal growth patterns at all sites within Rhode Island. This pattern paralleled those in more northerly locations with rapid growth in late winter/early spring and minimal growth in summer. There was no reduction in production at the Rhode Island sites, although they are near the southern limit of this species. L. digitata was found at the most exposed sites where it comprised up to $23 \%$ of the total kelp density. The relative contribution of kelp to the total primary productivity varies according to season. The epiphytic community was most abundant in August and September This study is the first report of 7 species of animals epiphytic on Laminaria spp. Lacuna vincta (Mollusca) was found to be an important grazer on the Laminaria blades especially in winter.
\end{abstract}

\section{INTRODUCTION}

Subtidal Laminaria zones are areas of intense primary productivity and large quantities of biomass in the northern hemisphere (see Kain, 1979 for review). Productivity of kelp has been measured in more northern areas, well within the latitudinal range of the species studied. Primary productivity of Laminaria spp. at the southern limit of its range is essentially unknown. Humm (1969) suggested that whereas some brown algae are limited at the southern end of their range by summer water temperatures when respiration exceeds photosynthesis, the same species may become adapted to warmer temperatures through natural variation. Hutchins (1947) proposed 2 relations that may control species distribution in the marine subtidal: (1) critical temperatures affecting individual survival; (2) critical temperatures needed to repopulate. The purpose of this study was to determine the extent to which Laminaria spp. were affected near their southernmost limit, Narragansett Bay and Rhode Island Sound (Taylor, 1972). The productivity of phytoplankton and zooplankton within Narragansett Bay has been measured (Smayda, 1957, 1973; Pratt, 1959, 1965; Furnas et al.,

\footnotetext{
- Present address: Zoology Department, University of New Hampshire, Durham, New Hampshire 03824, USA
}

1976; Durbin and Durbin, 1981), but the productivity of macroalgae and vascular plants of Narragansett Bay have been regarded as insignificant (Kremer and Nixon, 1978). In this study, the density and standing crop of $L$. saccharina and $L$. digitata were measured, as were growth rate, mortality and productivity of $L$. saccharina in Narragansett Bay and Rhode Island Sound.

\section{MATERIAL AND METHODS}

Site description

Narragansett Bay (NB) (Fig. 1) opens to the south into Rhode Island Sound (RIS). This bay has a total area of $259 \mathrm{~km}^{2}$, a maximum length of $42 \mathrm{~km}$ and an average width of 6 to $8 \mathrm{~km}$. Annual surface water temperatures range from -0.5 to $24^{\circ} \mathrm{C}$. Mean depth of the bay is $9 \mathrm{~m}$; maximum depth is $60 \mathrm{~m}$. The common sediment type in the northern bay is a mixture of silt-clay, sand and gravel; sand is predominant in the south. Shale, granite, and metamorphic rock are common to the southern subtidal zone of the bay; while the northern subtidal zone substratum is a cobble-sand mixture. Twenty-six locations were surveyed using a combination of SCUBA and free diving to determine distribution, density and width of the subtidal Laminaria sac- 
charina and L. digitata zone in Narragansett Bay and Rhode Island Sound. The locations were selected on the basis of substrata suitable for kelp attachment. Preliminary observations showed that the presence of kelp correlated with the following types of substrata: man-made, shale, granite, and offshore bedrock. A geological survey map of the substrata zones (Boothroyd and Al-Saud, 1978 in: Olsen et al., 1980) was used to determine the shoreline length within the kelp distribution range. The zones were measured with a map wheel (average of 5 measurements), and multiplied by a zone width derived from the distribution survey. The resulting value estimated the total area that could be occupied by kelp.

\section{Sample station selection}

Long-term sample stations (Fig. 1) were chosen from the distribution survey based on the following criteria: (a) existence of kelp beds of moderate to high density; (b) similar sample depths at all stations; (c) ease and safety of entering these stations throughout the year. The 2 stations in the southern portion of Narragansett Bay (NB) were: Fort Wetherill, Jamestown $\left(41^{\circ} 28.5^{\prime} \mathrm{N}\right.$, $\left.71^{\circ} 21.5^{\prime} \mathrm{W}\right)$ and Coaster's Harbor Island, Newport $\left(41^{\circ} 29^{\prime} \mathrm{N}, 71^{\circ} 19.9^{\prime} \mathrm{W}\right)$. One station outside the Bay in Rhode Island Sound (RIS), Land's End, Newport $\left(41^{\circ} 21.2^{\prime} \mathrm{N}, 71^{\circ} 18.6^{\prime} \mathrm{W}\right)$, was selected to compare with the 2 bay stations. The wave exposure at Coaster's Harbor Island, the northernmost study station, was more moderate than at the other stations, where it ranged from moderate to severe according to the season. Plants at Coaster's Harbor Island were harvested and tagged on a man-made stone wall, whereas at Ft. Wetherill and Land's End the substratum was cobble and bedrock.

\section{Growth rate measurements}

Meristematic growth rates of tagged Laminaria saccharina were determined using the standard hole punch procedure (Parke, 1948). Monthly measurements were recorded in situ using SCUBA at each of the 3 stations from April 1980 to June 1981. A hole $1.75 \mathrm{~cm}$ in diameter was punched $20 \mathrm{~cm}$ above the blade-stipe juncture to include the meristematic region of the blade (Parke, 1948; Mann, 1972b; Boden, 1979). Adult plants of uniform size were selected for growth measurements. Twenty individuals per station were tagged by placing a poultry wing tag at the base of the stipe. Holes were punched into the thallus after each sampling interval to measure the growth change during the next interval. These data $(\mathrm{cm}$ indi- vidual $I^{-1} \mathrm{~d}^{-1}$ ) were used in the subsequent calculations of primary productivity. The progress of the holes along the blades was recorded to determine the turnover of the blade length. Any plant lost during a sample interval was replaced by a newly tagged plant to maintain a sample size of 20 individuals at each station.

\section{Biomass and density measurements}

On the same days in which growth was measured, six $0.10 \mathrm{~m}^{2}$ quadrats of Laminaria spp. were harvested at each sample station. During periods of severe storms the frequency of sampling was reduced. Before sampling, the depth of maximum Laminaria spp. density was estimated visually by divers swimming perpendicular to depth contours within the laminarian zone. Four sampling transects $(A, B, C, D)$ within each study site were established, and quadrats were collected along these sampling transects. To avoid bias on the part of the divers, a random sampling technique was used to select the location of quadrats prior to the dive. For each quadrat to be collected, 3 location criteria were determined randomly: (1) transect (A, B, C or D); (2) direction from maximum density (shallow or deep); (3) distance from maximum density. Once the samples were returned to the laboratory, the following features were measured for all harvested plants: plant density per quadrat, species composition per quadrat and individual blade length, wet weight and dry weight (dried to a constant weight in a plant dryer, $35^{\circ} \mathrm{C}$ ). All individuals regardless of age class were counted to determine plant density.

The Kolmogorov-Smirnov test (Hollander and Wolfe, 1973) was used to determine whether the biomass and density data were normally distributed. The data were sorted and analysed by site (1) for the entire sample period and (2) at each sample date. A nonparametric 1way analysis of variance (Kruskal-Wallis test; Hollander and Wolfe, 1973) tested for significant differences in biomass and density between sample stations.

\section{Physical measurements}

Subtidal water temperature and surface salinity were measured on each sampling date. Subtidal water temperature was measured by the divers at the depth of maximum kelp density (1.5 to $3 \mathrm{~m}$ below MLW). Incident solar radiation data were obtained from Eppley Laboratories, Inc. (Newport, R. I.). Light intensity was measured at various depths within the laminarian zone with a Li-Cor Quantum Meter (Li-185). Extinction coefficients of the 3 sample stations were 
calculated from these light measurements. The mean annual extinction coefficients were $-0.150 \pm 0.030$ (SE) $\mathrm{m}^{-1}$ at Coaster's Harbor Island (NB), $-0.211 \pm$ $0.033(\mathrm{SE}) \mathrm{m}^{-1}$ at Ft. Wetherill $(\mathrm{NB})$ and $-0.239 \pm$ $0.085 \mathrm{~m}^{-1}$ (SE) at Land's End (RIS).

\section{Carbon analysis}

Six plants of Laminaria saccharina and 3 plants of L. digitata from the Ft. Wetherill sample station (collected March 1981) were dried to constant weight at $35^{\circ} \mathrm{C}$ and ground separately using a Wiley mill (mesh size \# 20). (Mann, 1972a found carbon to vary slightly in L. longicruris according to site or season.) The ground tissue was weighed (Perkin-Elmer Ultra Balance) and placed in preweighed aluminum boats. The samples were analysed for carbon content with a Horiba PIR-2000 Carbon Infrared Analyser while they were burned in a Lindberg Tube Furnace (compact style) at $950^{\circ} \mathrm{C}$. Combustion time depended on the return of the pen to the baseline. Oxygen was used as a carrier gas, at a flow rate of $1 \mathrm{l} \mathrm{m}^{-1}$. The method was standardized using a solution of anhydrous D-glucose (Mallinkrodt Co.), distilled water and mercury (poison inhibited bacterial growth).

\section{Calculation of net annual primary productivity and $\mathbf{P} / \mathbf{B}$}

Net annual primary productivity of the kelp for each station was calculated according to the following procedure:

(1) Various lengths of the Laminaria blade from the meristematic region of adult plants were dried to constant weight. A step-wise polynomial regression (Snedecor and Cochran, 1967) of dry weight to blade length was used to determine the appropriate regression formula.

(2) Data from growth rate measurements (mean blade length increase individual ${ }^{-1} \mathrm{mo}^{-1}$ ) were substituted in the above regression for blade length to determine mean increase in dry weight individual ${ }^{-1} \mathrm{mo}^{-1}$.

(3) Mean increase in dry weight individual ${ }^{-1} \mathrm{mo}^{-1}$ was multiplied by the ratio of carbon to dry weight to obtain the mean increase in carbon individual ${ }^{-1} \mathrm{mo}^{-1}$. These monthly values were summed for the year to determine net primary productivity ( $\mathrm{g} C$ individual ${ }^{-1} \mathrm{yr}^{-1}$ ).

(4) Net primary productivity (NPP) was multiplied by mean and median densities (individuals $\mathrm{m}^{-2}$ ) of each station to obtain primary productivity $\left(\mathrm{g} \mathrm{C} \mathrm{m}^{-2} \mathrm{yr}^{-1}\right)$ on an area basis.

(5) Production to biomass ratios (P/B) were computed for each sample station by multiplying the mean biomass produced per individual and the median density, then dividing the product by the median biomass of the harvested quadrats.

\section{Epiphyte assessment}

The macroalgal epiphytes found on harvested Laminaria spp. were carefully removed from the blades, placed in a $10 \%$ glutaraldehyde fixative with $0.1 \mathrm{M}$ phosphate buffer, and stored at $10^{\circ} \mathrm{C}$ until identified. Animals attached to, and associated with the Laminaria spp., were collected from the harvested individuals and stored at room temperature in a $70 \%$ alcohol solution.

\section{RESULTS}

\section{Distribution survey of Laminaria spp.}

Laminaria saccharina and $L$. digitata were limited to lower Narragansett Bay (NB) and Rhode Island Sound (RIS) (Fig. 1), where, in addition to suitable substrata,

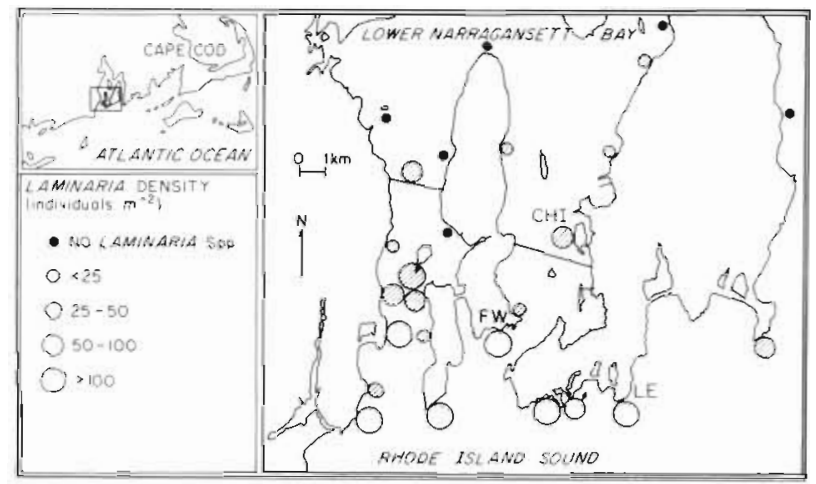

Fig. 1. Long-term study sites in Rhode Island, USA (CHI: Coaster's Harbor Island, FW: Ft. Wetherill, LE: Land's End). Distribution and density of the Laminaria spp. in Narragansett Bay and Rhode Island Sound are represented by circles. Stipple: $L$. saccharina and $L$. digitata present; hatch: $L$. saccharina only

there was greater wave exposure and less turbidity than the upper Bay (Schenck and Davis, 1973). The length of shoreline that kelp could occupy was estimated as $53 \mathrm{~km}$, and the mean kelp zone width as $6 \mathrm{~m}$. Therefore, the surface area in Narragansett Bay that could support the laminarian species is $0.32 \mathrm{~km}^{2}$. Not all the bedrock supports kelp, but kelp also occur sporadically on other substrata (e.g. cobble and sand). Thus the estimate of total area is reasonable. The kelp population was observed to have an extremely patchy distribution within the subtidal. However, L. saccharina grew sporadically in calmer waters $16 \mathrm{~km}$ 
north of the entrance to the Bay. Density was greatest on the southerly exposed shores within the Bay and Rhode Island Sound, and L. digitata could be found only at the stations with the greatest wave exposure.

\section{Seasonal growth of Laminaria saccharina}

Mean monthly meristematic growth rates $\left(\mathrm{cm} \mathrm{d}^{-1}\right)$ of individual plants showed a similar seasonal pattern at all 3 stations (Fig. 2). The maximum growth rate of $2 \mathrm{~cm} \mathrm{~d}^{-1}$ occurred in May and June when the subtidal water temperature was $13^{\circ} \mathrm{C}$ and incident solar radiation was nearly 500 langleys $\mathrm{d}^{-1}$ (Fig. 3). Little or no
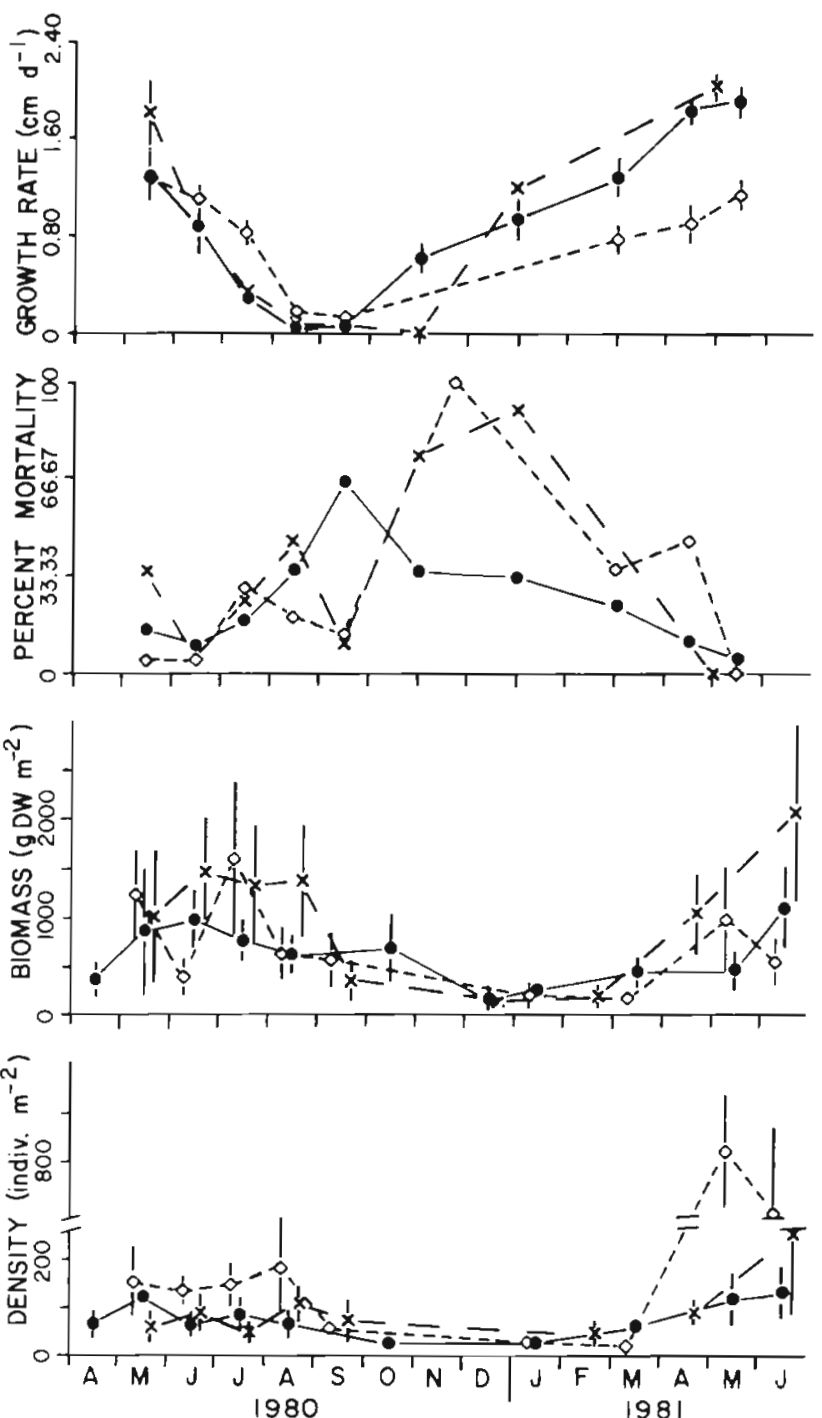

Fig. 2. Laminaria saccharina mean monthly meristematic growth rate, percent mortality of tagged individuals, mean standing crop and mean density at 3 study sites in Rhode Island, April, 1980 to June, 1981 Circles: Coaster's Harbor Island; diamonds: Ft. Wetherill; crosses: Land's End. Vertical lines: standard error
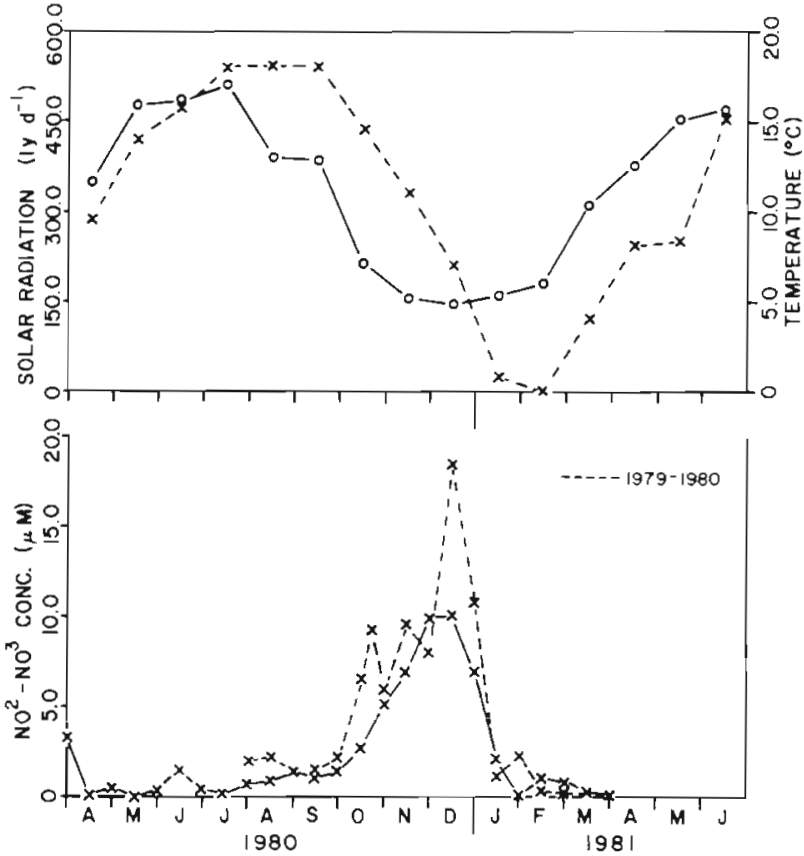

Fig. 3. Seasonal variation in subtidal water temperature and incident solar radiation in Narragansett Bay and Rhode Island Sound. Ambient nitrite and nitrate concentrations collected in Narragansett Bay at $1.5 \mathrm{~m}$ depth. Upper panel: circles = incident solar radiation and crosses = subtidal temperature. Lower panel: data were collected at the Marine Ecosystem Research Lab, Univ. of Rhode Island; C. Oviatt, pers. comm.

growth occurred in August and September when the subtidal water temperature was $17^{\circ} \mathrm{C}$ (Fig. 3) and the epiphyte community was observed to be most abundant. Salinity measurements at the 3 sample stations ranged from 30 to $34 \%$ through the year, and did not vary more than $1 \%$ from station to station. The highest mean annual growth rate was seen at Coaster's Harbor Island (NB) whereas the lowest was at Land's End (RIS) (Table 1). At the latter station, however, the greatest mean monthly growth rate was measured in spring 1981, but there was a slightly longer period of no growth during the summer of 1980 (Fig. 2).

Mean monthly mortality of the tagged individuals at all stations for the entire sample period (April 1980 to June 1981) was $29.3 \%$ (Fig. 2). No single plant survived the entire sample period. Maximum survival of a tagged plant was 9 mo. Maximum loss of tagged plants occurred in September at Coaster's Harbor Island (NB) and in November/January at Ft. Wetherill (NB) and Land's End (RIS) (Fig. 2).

\section{Seasonal biomass and density}

Laminaria at all 3 sample stations showed similar seasonal biomass fluctuations (Fig. 2). Standing crop 
Table 1. Laminaria saccharina. Meristematic growth rate, standing crop, density, net productivity, and P/B in kelp beds in Narragansett Bay (NB) and Rhode Island Sound (RIS), 1980-1981. Median values in parentheses

\begin{tabular}{|c|c|c|c|c|c|c|}
\hline Stations & $\begin{array}{c}\text { Mean } \\
\text { meristematic } \\
\text { growth rate } \\
\left(\mathrm{cm} \mathrm{d} d^{-1} \pm \mathrm{SE}\right)\end{array}$ & $\begin{array}{c}\text { Mean } \\
\text { and median } \\
\text { standing crop } \\
\text { (g DW } \mathrm{m}^{-2} \pm \mathrm{SE} \text { ) }\end{array}$ & $\begin{array}{c}\text { Mean } \\
\text { and median } \\
\text { density } \\
\text { (Ind. } \mathrm{m}^{-2} \pm \mathrm{SE} \text { ) }\end{array}$ & $\begin{array}{c}\text { Percentage } \\
\text { of } L . \text { saccharina } \\
\text { of total density } \\
(\%)\end{array}$ & $\begin{array}{c}\text { Annual } \\
\text { net primary } \\
\text { productivity } \\
\left(\mathrm{gC}^{-2} \mathrm{yr}^{-1}\right)\end{array}$ & $\mathrm{P} / \mathrm{B}$ \\
\hline $\begin{array}{l}\text { Coaster's Harbor } \\
\text { Island (NB) }\end{array}$ & $0.909 \pm 0.214$ & $606 \pm 93(367)$ & $76 \pm 11(40)$ & 100 & 1202 & 5.2 \\
\hline $\begin{array}{l}\text { Ft. Wetherill } \\
\text { (NB) }\end{array}$ & $0.802 \pm 0.152$ & $715 \pm 161(632)$ & $243 \pm 95(90)$ & $77-100$ & 3531 (1291) & 4.5 \\
\hline $\begin{array}{l}\text { Land's End } \\
\text { (RIS) }\end{array}$ & $0.796 \pm 0.286$ & $1000 \pm 217(536)$ & $95 \pm 23(50)$ & $93-100$ & $1099 \quad(577)$ & 3.6 \\
\hline
\end{tabular}

( $\mathrm{g} \mathrm{DW} \mathrm{m}^{-2}$ ) was highest in early summer and lowest during winter. Many of the plants that survived the winter eroded to within $20 \mathrm{~cm}$ of the blade-stipe juncture, thus reducing the biomass of the remaining population. This period was followed by a slow biomass increase in the spring. Land's End (RIS) had the highest annual mean standing crop while Ft. Wetherill (NB) had the highest annual median standing crop (Table 1). The standing crop of Coaster's Harbor Island (NB) was significantly lower than that of Ft. Wetherill (NB) (Kruskal-Wallis test, $p<0.002$ ). However, the individuals at Coaster's Harbor Island (NB) did not have a lower growth rate. The mean annual standing crops of $L$. saccharina at the sample stations within the Bay and Rhode Island Sound were $660 \pm 54 \mathrm{~g} \mathrm{DW} \mathrm{m}^{-2}$ $\left(\right.$ median $\left.=513 \mathrm{~g} \mathrm{DW} \mathrm{m}^{-2}\right)$ and $1000 \pm 217 \mathrm{~g} \mathrm{DW} \mathrm{m}^{-2}$ (median $=536 \mathrm{~g} \mathrm{DW} \mathrm{m}^{-2}$ ), respectively. The biomass lost from the experimental plants for the year sampled, based on the percentage of tagged plants lost and the mean individual dry weight of $L$, saccharina (15.1 g DW), was $699 \mathrm{~g}$ DW from Coaster's Harbor Island (NB), $685 \mathrm{~g}$ DW from Ft. Wetherill (NB), and 1,125 g DW from Land's End (RIS).

Blades of Laminaria saccharina renewed their length between 3 and 4 times during the year. A turnover rate of 3.5 was multiplied by the mean standing crop of the Narragansett Bay stations to determine the mean annual biomass production of $2310 \mathrm{~g} \mathrm{DW} \mathrm{m}^{-2} \mathrm{yr}^{-1}$. This value was multiplied by the calculated area of kelp cover $\left(0.32 \mathrm{~km}^{2}\right)$ to obtain a total Narragansett Bay annual biomass of $7.4 \times 10^{2}$ metric tons (DW).

The density (individuals $\mathrm{m}^{-2}$ ) of all age classes of Laminaria spp. showed a seasonal pattern similar to that of biomass (Fig. 2, Table 2) in that there was a rapid increase in density in the spring months and a decrease in density in the fall. The decrease in density was coincident with the greatest loss of tagged $L$. saccharina sporophytes (Fig. 2). L. digitata was found at 2

Table 2. Laminaria digitata. Monthly density (Ind. $\mathrm{m}^{-2} \pm \mathrm{SE}$ ) and standing crop (g DW $\mathrm{m}^{-2} \pm \mathrm{SE}$ ) in kelp beds in Narragansett Bay (NB) and Rhode Island Sound (RIS), 1980-1981. ND = No data

\begin{tabular}{|c|c|c|c|c|c|c|}
\hline \multirow[b]{2}{*}{ Date } & \multicolumn{2}{|c|}{$\begin{array}{l}\text { Coaster's Harbor } \\
\text { Island (NB) }\end{array}$} & \multicolumn{2}{|c|}{$\begin{array}{l}\text { Ft. Wetherill } \\
\text { (NB) }\end{array}$} & \multicolumn{2}{|c|}{$\begin{array}{l}\text { Land's End } \\
\text { (RIS) }\end{array}$} \\
\hline & Density & Standing crop & Density & Standing crop & Density & Standing crop \\
\hline May 1980 & 0 & 0 & $5 \pm 2$ & $454 \pm 381$ & $2 \pm 1$ & $48 \pm 48$ \\
\hline Jun & 0 & 0 & $10 \pm 1$ & $707 \pm 436$ & 0 & 0 \\
\hline Jul & 0 & 0 & $3 \pm 1$ & $425 \pm 270$ & $2 \pm 1$ & $63 \pm 63$ \\
\hline Aug & 0 & 0 & $2 \pm 1$ & $99 \pm 99$ & $5 \pm 2$ & $178 \pm 119$ \\
\hline Sep & 0 & 0 & 0 & 0 & $2 \pm 1$ & $42 \pm 42$ \\
\hline Oct & 0 & 0 & ND & ND & ND & ND \\
\hline Nov & 0 & 0 & ND & ND & ND & ND \\
\hline Dec & 0 & 0 & ND & ND & 0 & 0 \\
\hline $\operatorname{Jan} 1981$ & 0 & 0 & $10 \pm 3$ & $426 \pm 183$ & ND & ND \\
\hline Feb & 0 & 0 & ND & ND & $3 \pm 2$ & $49 \pm 33$ \\
\hline Mar & 0 & 0 & $5 \pm 1$ & $263 \pm 131$ & ND & ND \\
\hline Арт & 0 & 0 & ND & ND & 0 & 0 \\
\hline May & 0 & 0 & 0 & 0 & ND & $\mathrm{ND}$ \\
\hline Jun & $\underline{0}$ & $\underline{0}$ & $2 \pm 1$ & $104 \pm 104$ & $\underline{8 \pm 5}$ & $\underline{446 \pm 310}$ \\
\hline Yearly mean & 0 & 0 & 4 & 275 & 3 & 92 \\
\hline
\end{tabular}


of the 3 stations sampled (Ft. Whetherill and Land's End) and it always had a lower density than L. SaCcharina (Table 1). Neither young nor reproductive $L$. digitata sporophytes were common in the quadrats. The recruitment of young $L$. saccharina sporophytes ( $<50 \mathrm{~cm}$ in length) was most pronounced at Ft. Wetherill (NB) and Land's End (RIS). It was these young sporophytes that had settled in dense patches on bare substrata (before the settlement of other macroalgae) which appeared to be the individuals that survived and later became reproductive. The large standard error of the spring density measurements gives an indication of the patchy kelp distribution (Fig. 2). The majority of individuals sampled in spring were firstyear plants less than $80 \mathrm{~cm}$. The greatest density measured in spring 1981 in 1 quadrat was 1990 individuals $\mathrm{m}^{-2}$. Young sporophytes were found throughout most of the year. Sporophytes that settled during summer and fail, on the other hand, could attach only to other macroalgae already established (e.g. Chondrus crispus). The young laminarian plants were loosely attached to these algae and could easily be dislodged. Young sporophyte recruitment at Coaster's Harbor Island (NB) was much lower than at the other stations. It is important to note that the population sampled at Coaster's Harbor Island (NB) grew exclusively on vertical substrata (man-made wall) which may have affected the establishment of sporophytes. The greatest yearly mean and median density of kelp was measured at Ft. Wetherill (NB) (243 \pm 95 and 90 individuals $\mathrm{m}^{-2}$, respectively), where $L$. digitata was most abundant (Tables 1 and 2). The density at Ft. Wetherill (NB) was significantly higher than the density at Coaster's Harbor Island (NB) (Kruskal-Wallis test, $p<0.005$ ) and Land's End (RIS) $(p<0.05)$.

Median values have been included for standing crop and density results because the results of the Kolmogorov-Smirnov test indicated that the data were not normally distributed over the entire sample period. This is a result of few occurrences of very high values which would inflate the mean values. Therefore, the median may be a more accurate measure of the kelp population. There were few instances when biomass and density data were normally distributed at a particular station and sample date.

\section{Epiphyte community}

The epiphyte community was observed to be most abundant during August and September when kelp growth was negligible. At this time, the kelp were moribund and could be torn by wave action. Further observations indicated that epiphytes were at a
Table 3. Epiphytes commonly associated with Laminaria spp in Narragansett Bay and Rhode Island Sound, 1980-1981. Asterisks: species observed $>9$ mo of sample period

\begin{tabular}{|c|c|}
\hline Species & Phylum/Division \\
\hline \multicolumn{2}{|l|}{ Animals } \\
\hline Obelia sp. ${ }^{1}$ & Coelenterata \\
\hline Craterolophus convolvus & Coelenterata \\
\hline Mitrella lunata ${ }^{\circ}$ & Mollusca \\
\hline Lacuna vincta ${ }^{1}$ & Mollusca \\
\hline Littorina littorea & Mollusca \\
\hline Mytilus edulis ${ }^{2}$ & Mollusca \\
\hline Asterias forbesi ${ }^{2}$ & Echinodermata \\
\hline Spirorbis spirillum ${ }^{1}$ & Annelidà \\
\hline Didemnum candidum & Chordata \\
\hline Cryptosula pallasiana ${ }^{4}$ & Bryozoa \\
\hline Bugula turrita & Bryozoa \\
\hline Balanus sp. & Arthropoda \\
\hline Anoplopactylum lenus & Arthropoda \\
\hline \multicolumn{2}{|l|}{ Plants } \\
\hline Ulva lactuca ${ }^{3}$ & Chlorophyta \\
\hline Palmeria palmata ${ }^{1}$ & Rhodophyta \\
\hline Ceramium spp. ${ }^{3}$ & Rhodophyta \\
\hline Ectocarpus spp. ${ }^{3}$ & Phaeophyta \\
\hline \multicolumn{2}{|c|}{$\begin{array}{l}\text { Previously identified as an epiphyte by: } \\
{ }^{1} \text { Kain, J. M. (1979), reported on Laminaria spp. } \\
{ }^{2} \text { Edwards, A. (1980), reported on Laminaria hyperborea } \\
{ }^{3} \text { Tokida, J. (1960), reported on Laminaria spp. } \\
{ }^{4} \text { Smith, R. (1964), reported on Laminaria spp. }\end{array}$} \\
\hline
\end{tabular}

minimum in spring during maximal growth of kelp. Table 3 is a species list of the plant and animal epiphytes found within the kelp beds. Some genera (e.g. Spirorbis, Ulva) have been previously identified attached to or associated with Laminaria spp. (Tokida, 1960; Smith, 1964; Kain, 1979; Edwards, 1980). This is the first report of 7 species of animal epiphytes (e.g. Craterolophus convolvus, Bugula turrita). The predominant epiphytes on the blades were the invertebrates Bugula turrita (Bryozoa) and Obelia spp. (Coelenterata), while macroalgal epiphytes were more ephemeral, perhaps because of earlier colonization and dominance of animal epiphytes. Only 1 epiphytic animal, Lacuna vincta, grazed heavily on the blades and blade tips. Its activity was greatest during winter when L. saccharina blades were eroded to within $20 \mathrm{~cm}$ of the blade-stipe juncture. Epidermal cells of the kelp were clearly damaged and sometimes absent in areas where $L$. vincta was present. L. vincta was found on both species of kelp but was observed to be most abundant on $L$. saccharina throughout the year. When a kelp stand was adjacent to a bed of Mytilus edulis at the upper Bay site, byssal threads from the mussels were found attached to the kelp, reducing the movement of the blade. During extreme wave exposure, the blades would tear if anchored by the byssal threads. 


\section{Dry weight : blade length regression and tissue carbon analysis}

A linear regression of blade length and dry weight is the best fit for adult Laminaria saccharina (Fig. 4). This regression fornula is:

Dry weight $(\mathrm{gDW})=(0.15615)$ blade length $(\mathrm{cm})+1.6$ $r^{2}=0.80$

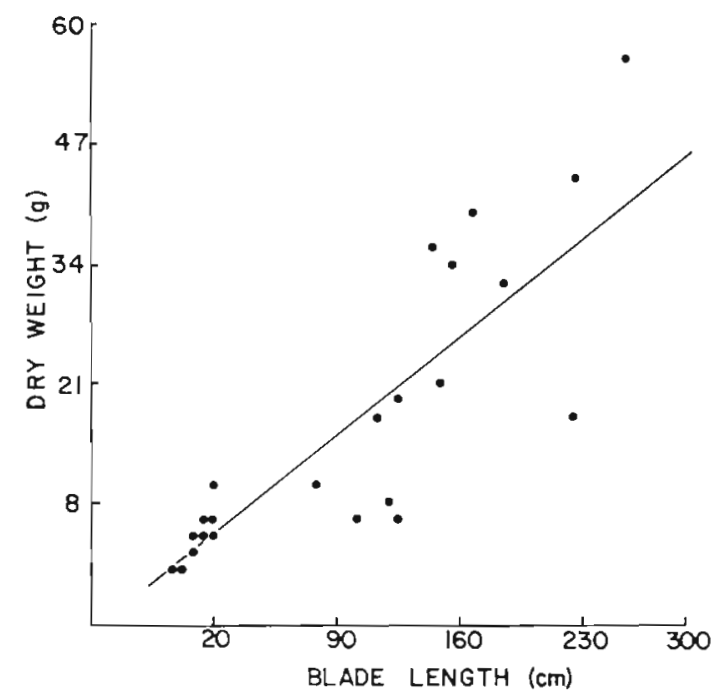

Fig. 4. Laminaria saccharina blade length and dry weight regression for adult plants

with a correlation coefficient of 0.89 (range $=0.84$ to $0.94 \alpha=0.05$ ). L. saccharina had a higher percent of tissue carbon $(31.5 \pm 3.4 \%)$ than L. digitata $(26.9 \pm 6.0 \%)$, but this difference was statistically not significant.

\section{Net annual primary productivity}

The kelp stand at Ft. Wetherill (NB) had a higher primary productivity on an area basis than Coaster's Harbor Island (NB) and Land's End (RIS) (Table 1). The mean and median primary productivity for the 2 stations within Narragansett Bay (2366 and $962 \mathrm{~g} \mathrm{C} \mathrm{m}^{-2}$ $\mathrm{yr}^{-1}$, respectively) were calculated by pooling data from the Narragansett Bay sample stations. The productivity when using median density was approximately half the productivity using the mean density. It can be argued that these productivity values are an overestimate because no distinction was made between juvenile and adults in the density measurements. The maximum productivity of Laminaria saccharina individuals ( 50 to $60 \%$ of the total) occurred in late winter and spring (Table 4), and the lowest was in August and September (0.4 to $2.2 \%$ of the total). The mean productivity per individual at the 3 stations for the year was $15.43 \pm 0.99 \mathrm{~g} \mathrm{C}^{\text {individual }}{ }^{-1} \mathrm{yr}^{-1}$.

\section{DISCUSSION}

The vegetative growth pattern of Laminaria saccharina at the 2 sample stations in Narragansett Bay was similar to that in Rhode Island Sound. The pattern agrees with results reported for $L$, longicruris in St. Margaret's Bay, Nova Scotia (Mann, 1972b; Chapman and Craigie, 1977; Gagne et al., 1982) (L. saccharina is thought to be conspecific with L. longicruris [Chapman, 1974]). This pattern has been regarded as a typical growth cycle of Laminaria spp., with rapid growth from late winter to late spring and minimal growth in summer, independent of environmental conditions (Kain, 1979). In some Laminaria populations, growth

Table 4. Laminaria saccharina. Monthly net production as \% of annual total production in Narragansett Bay (NB) and Rhode Island Sound (RIS), 1980-1981. Dash: missing data

\begin{tabular}{|c|c|c|c|c|c|c|}
\hline \multirow[b]{2}{*}{ Date } & \multicolumn{2}{|c|}{$\begin{array}{l}\text { Coaster's Harbor } \\
\text { Island (NB) }\end{array}$} & \multicolumn{2}{|c|}{$\begin{array}{l}\text { Ft. Wetherill } \\
\text { (NB) }\end{array}$} & \multicolumn{2}{|c|}{$\begin{array}{l}\text { Land's End } \\
\text { (RIS) }\end{array}$} \\
\hline & $g C$ ind. $^{-1}$ & $\begin{array}{c}\% \text { of annual } \\
\text { total }\end{array}$ & $\mathrm{g} C$ ind. $^{-1}$ & $\begin{array}{c}\% \text { of annual } \\
\text { total }\end{array}$ & $\mathrm{gC}$ ind. ${ }^{-1}$ & $\begin{array}{c}\% \text { of annual } \\
\text { total }\end{array}$ \\
\hline May 1980 & 2.03 & 12.8 & 2.20 & 15.4 & 2.79 & 17.3 \\
\hline Jun & 1.76 & 11.2 & 1.53 & 10.7 & 1.28 & 7.9 \\
\hline Jul & 0.42 & 2.7 & 1.45 & 10.1 & 0.68 & 4.2 \\
\hline Aug & 0.07 & 0.4 & 0.32 & 2.2 & 0.14 & 0.9 \\
\hline Sep & 0.19 & 1.2 & 0.21 & 1.5 & 0.12 & 0.7 \\
\hline Oct-Nov & 1.88 & 11.9 & - & & 0.22 & 1.4 \\
\hline Dec-Jan 1981 & 2.82 & 17.8 & - & $29.7^{\circ}$ & 4.14 & 25.6 \\
\hline Feb-Mar & 3.53 & 22.3 & 2.54 & 17.7 & -1 & 920 \\
\hline $\mathrm{Apr}$ & 3.12 & 19.7 & 1.81 & 12.7 & $-\quad\}$ & $42.0^{\circ}$ \\
\hline Annual total & $\overline{15.82}$ & $\overline{100.0}$ & $\overline{14.31}$ & $\overline{100.0}$ & $\overline{16.16}$ & $\overline{100.0}$ \\
\hline
\end{tabular}


differs from the typical pattern (Reynolds, 1974; Gerard and Mann, 1979; Gagne et al., 1982). This difference has been attributed to the concentration and duration of ambient nitrogen supplies; when the nitrogen supply is abundant, growth is correlated with the light cycle (Chapman and Craigie, 1977; Gagne et al., 1928). The growth pattern of Rhode Island plants resembled L. longicruris individuals in St. Margaret's Bay which were adapted to short periods of ambient nitrogen availability (Gagne et al., 1982). The ambient nitrogen and inorganic tissue nitrate cycles of plants in Narragansett Bay (Fig. 3; Asare and Harlin, 1983) are similar to those of St. Margaret's Bay (Gagne et al., 1982). This similarity adds support to the hypothesis that Laminaria growth is adapted to a combination of local environmental factors.

The mean annual biomass of Laminaria saccharina and $L$. digitata at the 2 sample stations in Narragansett Bay $\left(0.779 \mathrm{~kg} \mathrm{DW} \mathrm{m} \mathrm{m}^{-2}\right.$ [median $\left.\left.=0.513 \mathrm{~kg} \mathrm{DW} \mathrm{m}^{-2}\right]\right)$ and the 1 in Rhode Island Sound $\left(1.092 \mathrm{~kg} \mathrm{DW} \mathrm{m}^{-2}\right.$ [median $=0.536 \mathrm{~kg} \mathrm{DW} \mathrm{m}{ }^{-2}$ ]) are lower than those measured for comparable Laminaria spp. in St. Margaret's Bay, Nova Scotia (summer) (Mann, 1972a) and Helgoland, F. R. Germany (late summer/early fall) (Luining, 1969) (Table 5). The 2 previous studies had a harvesting time frame of 3 to 4 mo, when standing crop might have been at its maximum, as demonstrated by the results of this study (Fig. 2).

There was a $30 \%$ difference between the bladelength turnover rate calculated for Laminaria longicruris in Nova Scotia (5 times yr ${ }^{-1}$ ) (Mann, 1972b) and the rate calculated for L. saccharina in Narragansett Bay ( 3.5 times $\mathrm{yr}^{-1}$ ). However, Mann (1972b) has found increases in biomass to vary according to size classes of plants, and calculated a biomass turnover rate ranging from 4 to 10 times $\mathrm{yr}^{-1}$. The biomass turnover rate was not calculated for the present study. However, if Mann's (1972b) biomass turnover rate (rather than blade-length turnover rate) was multiplied by the Narragansett Bay standing crop, the mean annual kelp biomass for Narragansett Bay sample stations (2310 g DW $\mathrm{m}^{-2} \mathrm{yr}^{-1}$ ) would double.

For the entire Bay, the relative productivity of phytoplankton is 2 orders of magnitude higher than the kelp production, when the area of occurrence of kelp $\left(0.32 \mathrm{~km}^{2}\right)$ is considered. Within the kelp beds, the productivity of kelp (based on either mean or median density) is 2 to 10 times greater than the productivity of phytoplankton (308 $\mathrm{g} \mathrm{C} \mathrm{m}^{-2} \mathrm{yr}^{-1}$ ) (Furnas et al., 1976). Therefore, kelp within the narrow range of its distribution provides greater primary productivity in the lower Bay than previously realized.

There was a narrow temporal overlap in the distribution of primary production of phytoplankton and kelp in Narragansett Bay. Approximately $60 \%$ of the kelp production occurred from January to June (Table 4) when $17 \%$ of the phytoplankton production occurred (Furnas et al., 1976). Sixty \% of the total kelp production equals $4.5 \times 10^{8} \mathrm{~g} \mathrm{C} \mathrm{yr}^{-1}$ while $17 \%$ of the total phytoplankton production is $4.6 \times 10^{9} \mathrm{~g} \mathrm{C} \mathrm{yr}^{-1}$ in the lower Bay. The relative contribution of kelp to total primary production varies with the season: in winter. the carbon production of the kelp is $\sim 10 \%$ that of the phytoplankton; in summer, this value is much less.

Narragansett Bay kelp productivity exceeds the kelp productivity in Nova Scotia calculated by Hatcher et al. (1977), due to a difference in kelp density at the 2 study areas (Table 5). The primary productivity of individuals ( $\mathrm{g} C$ individual ${ }^{-1} \mathrm{yr}^{-1}$ ) in Nova Scotia was double (28 $\mathrm{g} \mathrm{C}$ individual $^{-1} \mathrm{yr}^{-1}$ ) (Hatcher et al., 1977) that of individuals in Narragansett Bay $(15.43 \pm 0.99 \mathrm{~g}$ $\mathrm{C}$ individual ${ }^{-1} \mathrm{yr}^{-1}$ ) (Table 4), suggesting greater productivity on an individual basis (rather than an areal basis) in northern areas. Table 5 compares productivity of other kelp communities. The Narragansett Bay kelp productivity was comparable to that in Spain (Lapointe et al, 1981), and it was greater than the productivity of Laminaria saccharina in Scotland (Johnston et al., 1977 ) and of $L$. longicruris in Nova Scotia (Hatcher et al., 1977). This was noteworthy considering that Narragansett Bay is near the southern limit for the species (Taylor, 1972)

Production to biomass $(\mathrm{P} / \mathrm{B})$ ratios provide information useful in describing the relative stage of a biological community (Odum, 1968). The $\mathrm{P} / \mathrm{B}$ ratios in this study ranged from 5.2 at Coaster's Harbor Island to 3.6 at Land's End. The $\mathrm{P} / \mathrm{B}$ decreased from sheltered to exposed areas (Table 1), consistent with the results from St. Margaret's Bay (Mann, 1972b), even though $\mathrm{P} / \mathrm{B}$ ratios from Nova Scotia were double those of Narragansett Bay. A similarity of temporal P/B ratios was found between those calculated by Lapointe et al. (1981) (where P/B decreased from 0.03 in January to 0.01 in July), and those of this study (where $P / B$ decreased from 0.02 to 0.005 for the same months). This decrease in $P / B$ is thought to be the result of succession from an immature to a mature community (Odum, 1968). The temporal pattern of $\mathrm{P} / \mathrm{B}$ may also represent the seasonal changes of the subtidal community where frequent abiotic disturbances cause a decline of the relative production of the community.

Laminaria spp. density in Rhode Island was variable and the annual mean and median densities in the subtidal were greater than those in Europe (Kain, 1979). The high density and variability measured in spring was the result of the patchy distribution of first year plants, as had been noted previously in European Laminaria populations (Kain, 1979). L. japonica var. ochotenis (in Japan) is the only other species that has a density comparable to that of $L$. saccharina (in Rhode 
Table 5. Representative standing crop and net primary production of Laminaria spp. communities

\begin{tabular}{|c|c|c|c|c|c|c|}
\hline \multirow[t]{2}{*}{ Location } & \multirow[t]{2}{*}{ Reference } & \multicolumn{2}{|c|}{ Standing crop } & \multirow{2}{*}{$\begin{array}{c}\text { Net } \\
\text { production } \\
\left(\mathrm{g} \mathrm{Cm}^{-2} \mathrm{ys}^{-1}\right)\end{array}$} & \multirow{2}{*}{$\begin{array}{l}\text { Period } \\
\text { sampled }\end{array}$} & \multirow[t]{2}{*}{ Species } \\
\hline & & $\begin{array}{c}\text { WW } \\
\mathrm{kg} \mathrm{m}^{-2}\end{array}$ & $\begin{array}{c}\mathrm{DW} \\
\mathrm{kg} \mathrm{m}^{-2}\end{array}$ & & & \\
\hline $\begin{array}{l}\text { Helgoland, } \\
\text { F.R. Germany }\end{array}$ & Lüning (1969) & 12.71 & $2.67^{\circ}$ & - & Aug-Nov & $\begin{array}{l}L . \text { saccharina } \\
\text { and } L \text {. digitata }\end{array}$ \\
\hline $\begin{array}{l}\text { Nova Scotia, } \\
\text { Canada }\end{array}$ & Mann (1972a) & 16.00 & $3.36^{\circ}$ & - & Jun-Aug & $\begin{array}{l}\text { L. longicruris } \\
\text { and } L \text {. digitata }\end{array}$ \\
\hline $\begin{array}{l}\text { Nova Scotia, } \\
\text { Cânada }\end{array}$ & $\begin{array}{l}\text { Hatcher et al. } \\
\text { (1977) }\end{array}$ & - & - & $143-428$ & May-May & L. longicruris \\
\hline $\begin{array}{l}\text { Loch Creran, } \\
\text { Scotland }\end{array}$ & $\begin{array}{l}\text { Johnston et al. } \\
(1977)\end{array}$ & - & - & 120 & Jan-Dec & L. saccharina \\
\hline $\begin{array}{l}\text { Lagoon Pt. } \\
\text { Alaska USA }\end{array}$ & $\begin{array}{l}\text { Calvin and Ellis } \\
(1978)\end{array}$ & 14.50 & $3.05^{*}$ & - & May & L. dentigera \\
\hline $\begin{array}{l}\text { Ria de Arosa, } \\
\text { Spain }\end{array}$ & $\begin{array}{l}\text { Lapointe et al. } \\
\text { (1981) }\end{array}$ & - & - & $292-4380^{\circ}$ & Sep-Jul & $\begin{array}{l}\text { Laminaria spp. } \\
\text { and other genera }\end{array}$ \\
\hline $\begin{array}{l}\text { Narragansett Bay } \\
\text { and R.I. Sound USA }\end{array}$ & This study & - & $0.2-6.0$ & $\begin{array}{l}2366 \text { (mean) } \\
962 \text { (median) }\end{array}$ & Apr 80-Jun 81 & $\begin{array}{l}\text { L. saccharina } \\
\text { and L. digitata }\end{array}$ \\
\hline
\end{tabular}

Island) (Kaneko and Nihara, 1977). L. saccharina remains the dominant species over $L$. digitata at any depth within the subtidal zone in Rhode Island.

Herbivore grazing of Laminaria spp. in Rhode Island was primarily due to Lacuna vincta, a prosobranch gastropod. L. vincta caused extensive damage on Laminaria populations in New Hampshire (Fralick et al., 1974). The green sea urchin, Strongylocentrotus droebachiensis, grazes on kelp in Nova Scotia (Mann, 1973). However, S. droebachiensis is limited to deeper waters in Rhode Island and is not found within the kelp beds; therefore, sea urchin grazing was not evident (own obs.).

This study supports earlier estimates that Narragansett Bay is a phytoplankton-based system (Kremer and Nixon, 1978). However, the data show that the macroalgae are more productive than previously credited, especially the Laminariales (which represent only a portion of the total macroalgae). Our values for the primary productivity of kelp may be an underestimate because factors such as spore release, biomass turnover (rather than blade-length turnover), and exudation, have not been included. This study and others (Mann, 1973; Johnston et al., 1977; Lapointe et al., 1981) have shown that kelp provide substrata, habitat and food for other subtidal inhabitants. Thus, the laminarians may contribute even more to the Narragansett Bay ecosystem than the scope of this study has examined.

In conclusion, Laminaria saccharina and L. digitata are as productive near their southern range limit as observed in studies well within the distributional range. Net primary productivity, growth rates, standing crop and tissue carbon were within the range and/ or similar to results of other kelp studies (Kain, 1979). However, there were dissimilar results in the following: (a) population density was extremely variable but on the average the density was higher than in Nova Scotia for L. longicruris (Hatcher et al., 1977) and in Great Britain for L. hyperborea (Kain, 1979); (b) the rate of blade-length turnover was less than that measured in Nova Scotia (Mann, 1972b); (c) productivity of individual plants was $\sim 50 \%$ less than for $L$. longicruris in Nova Scotia (Hatcher et al., 1977); and (d) P/B ratios for the Rhode Island population of $L$. saccharina were approximately half those of the L. longicruris population in Nova Scotia.

Acknowledgements. We thank Drs. Candace Oviatt, Keith Killingbeck, David Pratt, and the University of Rhode Island Diving Program for help, and the US Department of Navy for access to the Coaster's Harbor Island site. Special thanks are expressed to Drs. Arthur Mathieson, Kenneth Mann, and 3 anonymous reviewers who offered valuable suggestions in the final stages of the manuscript. The study was supported in part by a Sigma XI Grant-in-aid of Research awarded to M.B.C. This paper is contribution \# 1 of the Newport Marine Biological Research Project.

\section{LITERATURE CITED}

Asare, S., Harlin, M. M. (1983). Seasonal fluctuations in tissue nitrogen for five species of perennial macroalgae in Rhode Island Sound. J. Phycol. 19: 248-251

Boden, G. (1979). The effect of depth on summer growth of Laminaria saccharina. Phycologia 18: 405-408 
Calvin, N. I., Ellis, R. J. (1978). Quantitative and qualitative observations on Laminaria digitata and other subtidal kelps of southern Kodiak Island, Alaska. Mar. Biol. 47 $331-336$

Chapman, A. R. O. (1974). The genetic basis of morphological differentiation in some Laminaria populations. Mar Biol. 24: 85-91

Chapman, A. R. O., Craigie, J. S. (1977). Seasonal growth in Laminaria longicruris: relations with dissolved inorganic nutrients and internal reserves of nitrogen. Mar. Biol. 40: $197-205$

Durbin, A. G., Durbin, E. G. (1981). Standing stock and estimated production rates of phytoplankton and zooplankton in Narragansett Bay, Rhode Island. Estuaries 4: 24-41

Edwards, A. (1980). Ecological studies of the kelp, Laminaria hyperborea, and its associated fauna in southwest Ireland. Ophelia 19: 47-60

Fralick, R. A., Turgeon, K. W., Mathieson, A. C. (1974). Destruction of kelp populations by Lacuna vincta (Montagu). Nautilus 88: 112-114

Furnas, M., Hitchcock, G., Smayda, T. (1976). Nutrient-phytoplankton relationship in Narragansett Bay during 1974 summer bloom. Estuar. Proc. 1: 118-133

Gagne, J., Mann, K., Chapman, A. R. O. (1982), Seasonal patterns of growth and storage in Laminaria longicruris in relation to differing patterns of availability of nitrogen in the water. Mar. Biol. 69: 91-101

Gerard, V., Mann, K. H. (1979). Growth and production of Laminaria longicruris (Phaeophyta) populations exposed to different intensities of water movement. J. Phycol. 15: $33-41$

Hatcher, B. G., Chapman, A. R. O., Mann, K. H. (1977). An annual carbon budget for the kelp Laminaria longicruris. Mar, Biol. 44: 85-96

Hollander, M., Wolfe, D. A. (1973). Non-parametric statistical methods. J. Wiley \& Sons, Inc., New York

Humm, H. J. (1969). Distribution of marine algae along the Atlantic Coast of North America. Phycologia 7: 43-53

Hutchins, L. W. (1947). The basis for temperature zonation in geographical distribution. Ecol. Monogr. 17: 325-335

Johnston, C. S., Jones, R. G., Hunt, R. D. (1977). A seasonal carbon budget for a laminarian population in a Scottish sea-loch. Helgoländer Meeresunters. 30: 527-545

Kain, J. M. (1979). A view of the genus Laminaria. Oceanogr. mar Biol. A. Rev. 17: 101-161

Kaneko, T., Nihara, Y (1977). Annual change of the vertical distribution of Laminaria japonica var. ochotensis at Rishiri Island, Hokkaido. J. Phycol. 13 (Suppl.): 34

Kremer, J. N., Nixon, S. W. (1978). A coastal marine ecosys- tem simulation and analysis. Ecological Studies \# 24. Springer-Verlag, New York

Lapointe, B. E., Niell, F. X., Fuentes, J. M. (1981). Community structure, succession and production of seaweeds associated with mussel-rafts in the Ria de Arosa, N. W. Spain. Mar. Ecol, Prog. Ser. 5: 243-253

Lüning, K. (1969). Standing crop and leaf area index of the sublittoral Laminaria species near Helgoland. Mar. Biol. 3: $282-286$

Mann, K. H. (1972a). Ecological energetics of the seaweed zone in a marine bay on the Atlantic coast of Canada. I. Zonation and biomass of seaweeds. Mar. Biol. 12: 1-10

Mann, K. H. (1972b). Ecological energetics of the seaweed zone in a marine bay on the Atlantic coast of Canada. II Productivity of the seaweeds. Mar. Biol. 14: 199-209

Mann, K. H. (1973). Seaweeds: their productivity and strategy for growth. Science, N. Y. 182: 975-981

Odum, E. P. (1968). Energy flow in ecosystems: a historical review. Am. Zool. 8: 11-18

Olsen, S., Robadue, D., Lee, V. (ed.) (1980). An interpretive Atlas of Narragansett Bay, Marine Bulletin 40. University of Rhode Island Coastal Resources Center

Parke, M. (1948). Studies on British Laminariaceae. I. Growth in Laminaria saccharina (L.). Lamour. J. mar. biol. Ass U. K. 27: 651-709

Pratt, D. M. (1959). The phytoplankton of Narragansett Bay Limnol. Oceanogr. 4: 425-440

Pratt, D. M. (1965). The winter-spring diatom flowering in Narragansett Bay. Limnol. Oceanogr. 10: 173-184

Reynolds, N. B. (1974). The growth of some New England perennial seaweeds. Rhodora 76: 59-63

Schenck, H., Davis, A. (1973). A turbidity survey of Narragansett Bay. Ocean Engng 2: 169-178

Smayda, T. J. (1957). Phytoplankton studies in lower Narragansett Bay. Limnol. Oceanogr. 2: 342-359

Smayda, T. J. (1973). A survey of phytoplankton dynamics in the coastal waters from Cape Hatteras to Nantucket. In: Coastal and Offshore Environmental Inventory, Cape Hatteras to Nantucket Shoals. Univ, of Rhode Island Mar. Publ. Ser. No, 2, p. 1-100

Smith, R. I. (ed.) (1964). Keys to marine invertebrates of the Woods Hole Region. Contribution \# 11. Marine Biological Laboratory Woods Hole, MA.

Snedecor, G. W., Cochran, W. G. (1967). Statistical methods lowa State University Press, Ames, Iowa

Taylor, W. R. (1972). Marine algae of the northeastern coast of North America. University of Michigan Press, Ann Arbor

Tokida, J. (1960). Marine algae epiphytic on Laminariales. Bull. Fac. Fish. Hokkaido Univ. 11: 73-105 